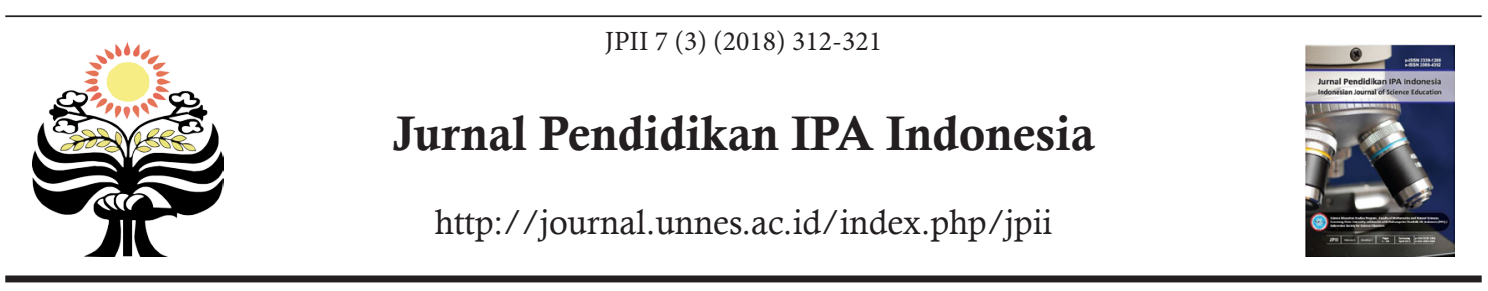

\title{
TWO PROBLEM SOLVING CYCLES TO ACHIEVE LEARNING OUTCOMES OF THINKING SKILLS AND PLANT ANATOMY CONCEPT MASTERY
}

\author{
R. P. Puspitawati*1, L. Yuanita ${ }^{2}$, Y. S. Rahayu ${ }^{3}$, S. Indana ${ }^{4}$, E. Susiyawati ${ }^{5}$ \\ 1,2,3,4 Universitas Negeri Surabaya, Surabaya, Indonesia \\ ${ }^{5}$ School of Education, Curtin University, Western Australia
}

DOI: 10.15294/jpii.v7i3.14295

Accepted: May 31 $1^{\text {st }}$ 2018. Approved: August 31 $1^{\text {st }}, 2018$. Published: September $20^{\text {th }}, 2018$

\begin{abstract}
The purpose of this study was to measure the effectiveness of two problem-solving cycles. The effectiveness of thinking skills was measured through the achievement of learning outcomes of problem solving skills and mastery of the concept of Plant Anatomy. The study was conducted on 96 students at Plant Anatomy course. The research type was quantitative research with a quasi-experiment method. The research design used one group pretest-posttest design. The collected data were analysed descriptively based on the percentage of learning mastery and the average of $\mathrm{N}$-gain. The data indicated a significant difference in the students' problem-solving skills between the pre-test and post-test with the $\mathrm{N}$-gain value was categorized as a medium level. Moreover, $75 \%$ of learning indicators have been completed by the students. In relation to the conceptual understanding, the results showed that the percentages of students who could complete the topics of a stem, a root, and a leaf were 80,21\%, $71,88 \%$, and $84,98 \%$, respectively. Therefore, it suggested that the two cycles of problem-solving cycles implemented in this study were effective.
\end{abstract}

(C) 2018 Science Education Study Program FMIPA UNNES Semarang

Keywords: problem solving, thinking skills, plant anatomy

\section{INTRODUCTION}

Regular cognitive skills show a significant decline in the 21st Century, while demands on high-level thinking skills and complex communications propose significant year-to-year increases. Thinking skills are the main competency to solve problems, especially high-level thinking skills. The high-level thinking, including problem-solving skills, is very important for students to have in order to deal with the competitive job world (Mavinkurve \& Patil, 2016; Isaria et al., 2016; Rotherham, 2010).

Problem-solving is a process to achieve goals in complex problems (Wang \& Chiew, 2010;

*Correspondence Address

E-mail: riniepratiwi@unesa.ac.id
Fischer et al., 2015, Effendi, 2016). In addition, good problem-solving skills can help students transfer their knowledge and understand the physical situation. Problem-solving skills should be trained at all levels of education to address the 21st-century challenges (Kirmizi, 2015; OECD, 2013). Problem-solving skills are individual competence to find solutions in various problems through logical means (OECD, 2014; Dostal, 2015; Demirel, 2015). These skills are the basis for constructing knowledge and increasing effective independent learning (Finch, 1999; Lesh \& Zawojewski, 2007; Chou \& Chen, 2009.).

Mostly, the results of the continuous research by PISSA show that the problem-solving skills in Higher Order Thinking Skills of Indonesian students were deficient (OECD, 2013; 
OECD, 2016). Research on problem-solving skills for students who took morphology and anatomy courses also show dissatisfying results (Puspitawati, 2017). The context of learning experienced by students becomes one of the factors causing low critical thinking and problem-solving skills. Problem-solving skills are trained and obtained in the context of specific materials through specific strategies (Hoskinson, et al., 2013).

Efforts to train problem-solving skills through a problem-solving strategy related to Plant Anatomy material contexts indicated high results for problem-solving skill mastery but low for Plant Anatomy concept mastery (Prastiwi \& Indah, 2012). It is possible that students tend to memorize only the same problems they had previously encountered to be repeated and applied on another problem resolution. This is because most students do not solve the problem by analyzing the situation and applying the concept to get the answer. Few students can apply a scientific approach to solve problems since they lack concepts (Riantoni et al., 2017).

Students' achievements during the implementation of problem-based learning tend to the repetition of existing theories instead of the discovery of a new concept. The success of students' learning is indicated by the number of concepts that they have learned without giving an emphasis how the concepts are related each other (Yew et al., 2011). Students' learning achievement is an accumulative process which involves collaborative learning. Another scholar recommended the need of different studies in organizing knowledge that may affect the use of knowledge in new contexts (Schmidt et al., 2011). The implementation of problem-based learning can be categorized into three types: (1) information is processed using the principles of mental model construction; (2) learning process is oriented to problem-solving and reasoning skills; and (3) learning strategy supports students to learn learning skills (Schmidt et al., 2011).

The research results have provided an opportunity to manage learning that can help students use problem-solving skills based on their concept mastery. Students who can solve problems characterize that they know the concept and have good problem-solving skills.

In this study, the learning management consisted of two problem-solving cycles to achieve the learning outcomes of Plant Anatomy concepts and problem-solving skills. The problem solving itself generally consists of several stages like orientation to the problem, defining and formulating problems, formulating or finding alternatives, making decisions and verification (Phungsuk et al., 2017; Jayaram et al., 2010; Cooperrider \& Whitney, 2010).

The learning management steps with two problem-solving cycles are illustrated as in (Figure 1)

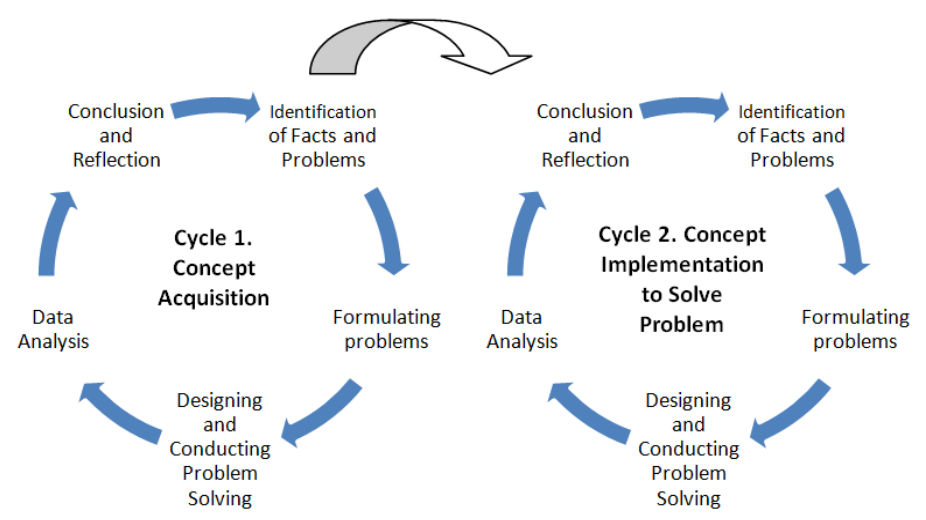

Figure 1. Two Problem Solving Cycles for Acquiring Concepts and Problem Solving Skills

The stages of problem-solving learning in each cycle consisted of (1) identifying the problems; (2) formulating the problems; (3) designing \& implementing problem-solving steps; (4) analyzing results; and (5) concluding and reflecting. The first cycle focused on acquiring the concept of plant anatomy, followed by the second cycle to implement the concept of the complex problem conditions associated with plant anatomical phenomena. These two cycles allowed the students to apply their concepts through a scientific approach to solve problems (Riantoni et al., 2017). The two cycles were activity-based, so, it was an entity that could eliminate the tendency of the students to memorize similar problem-solving steps to be repeated and applied to another problem. 
Activities in the two cycles were exploring facts and concepts to tackle the skills of analyzing, and solving problems, while also facilitating the students to the concept mastery. Exploration activities of facts and concepts were highly relevant to the content characteristics of plant anatomy materials. Plant anatomy materials present both factual and conceptual knowledge when it comes to studying the structure and function of plants. Procedural knowledge will be conveyed through the material content of the development of the anatomical structures. A factual, conceptual, and procedural review can be applied to describe phenomena, comparing two variables by examining differences and equations, as well as assessing causal correlations among variables associated with plant anatomical structures. The knowledge implemented for that is metacognitive knowledge.

The material characteristics described above are strong reasons to train problem-solving skills through plant anatomy materials. The problem-solving skills trained in each topic on plant anatomy materials will enrich the students' experience, as they relate the content to the concept application in the problem-solving process. The learning management is relevant to the cognitive-social theory which emphasizes that learning is the process of interaction and observing the environment through direct involvement (Moreno, 2010).

The purpose of this study is to determine the effectiveness of two problem-solving cycles seen from the learning outcomes of problemsolving skills and plant anatomy concept mastery. The problem proposed through this research was whether the two problem-solving cycles were effective to achieve the plant anatomy concepts mastery as well as problem-solving skills.
The effectiveness of the two cycles was based on (1) achievement of problem-solving skill indicators, (2) achievement of plant anatomy concept mastery indicators.

\section{METHODS}

This study followed the Pre-Experimental Designs of 'one-shot case study' (Fraenkel, Wallen, \& Hyun, 2012; Creswell, 2014; Tuckman \& Harper, 2012). This study was conducted on 96 students of Unesa Biology Education program, class of 2013/2014. The students were divided into three groups $(\mathrm{A}, \mathrm{B}$, and $\mathrm{U})$ having respectively 36,43 and 17 students each. This study was conducted at the even semester of 2016/2017 for 9 weeks. The lectures were held from February - June 2017 in Biology Department of FMIPA UNESA. The implementation of two cycles in these lectures was supported by the teaching materials, student activity guides, lecture courses, and valid assessment sheets.

The independent variable in this research was two problem-solving cycles. While the responded variable in this research was: (1) achievement of problem-solving skill indicators; and (2) achievement of plant anatomy concept mastery indicators. The indicators of problem-solving skills trained included eight skills, namely (1) identifying facts; (2) formulating questions; (3) formulating temporary answers; (4) identifying relevant factors; (5) determining alternative problem solving; (6) analyzing the results; (7) concluding; and (8) arranging the work plan (Airey \& Linder 2009, Gormally et al., 2009; Henderson, et al. 2011). The indicators of mastery of anatomical concepts include mastery of concepts on the topics of stems, roots, and leaves (Table 1).

Table 1. The Plant Anatomy Concept Indicators

\begin{tabular}{llll}
\hline No & \multicolumn{1}{c}{ Indicators on Sub Topics } \\
\hline 1. $\quad \begin{array}{l}\text { Stem } \\
\text { structure }\end{array}$ & \multicolumn{1}{c}{ Root } & \multicolumn{1}{c}{ Leaf } \\
2. $\quad \begin{array}{l}\text { Describing the structure and tissue } \\
\text { of the stem cortexconstituents }\end{array}$ & $\begin{array}{l}\text { Describing the root epidermal } \\
\text { tissue of the root cortexconstitu- } \\
\text { ents }\end{array}$ & $\begin{array}{l}\text { Describing the systolic structure } \\
\text { ture }\end{array}$ \\
3. $\quad \begin{array}{l}\text { Describing the stem endodermic } \\
\text { structure. }\end{array}$ & $\begin{array}{l}\text { Describing the root endodermic } \\
\text { structure. }\end{array}$ & $\begin{array}{l}\text { Describing the palisade struc- } \\
\text { ture }\end{array}$ \\
4. $\quad \begin{array}{l}\text { Describing the structure of the } \\
\text { stem vessel constituents. }\end{array}$ & $\begin{array}{l}\text { Describing the structure of the } \\
\text { root vessel constituents. } \\
\text { Describing the structure of the }\end{array}$ & $\begin{array}{l}\text { Describing the structure of } \\
\text { Describing the structure of the } \\
\text { sponsa }\end{array}$ \\
xylem tissue. & $\begin{array}{l}\text { Describing the stoma structure } \\
\text { based on its type }\end{array}$ \\
\hline
\end{tabular}




\begin{tabular}{|c|c|c|c|}
\hline 6. & $\begin{array}{l}\text { Describing the structure of the } \\
\text { phloem tissue. }\end{array}$ & $\begin{array}{l}\text { Describing the structure of the } \\
\text { phloem tissue. }\end{array}$ & $\begin{array}{l}\text { Mentioning the special features } \\
\text { of gymnosperm leaves }\end{array}$ \\
\hline 7. & $\begin{array}{l}\text { Describing the structure of the } \\
\text { stem pith parenchyma. }\end{array}$ & $\begin{array}{l}\text { Describing the structure of the } \\
\text { root pith parenchyma. }\end{array}$ & $\begin{array}{l}\text { Describing the leaf epidermal } \\
\text { abaxial structure }\end{array}$ \\
\hline 8. & $\begin{array}{l}\text { Summing up the stem anomaly } \\
\text { structure. }\end{array}$ & $\begin{array}{l}\text { Summing up the root anomaly } \\
\text { structure. }\end{array}$ & $\begin{array}{l}\text { Describing the crystal structure } \\
\text { on the leaf base tissue }\end{array}$ \\
\hline 9. & $\begin{array}{l}\text { Describing arguments on the stem } \\
\text { anomaly structure }\end{array}$ & $\begin{array}{l}\text { Describing arguments on the } \\
\text { root anomaly structure }\end{array}$ & $\begin{array}{l}\text { Describing the trichome struc- } \\
\text { ture based on its type }\end{array}$ \\
\hline 10 . & $\begin{array}{l}\text { Concluding the occurrence of sec- } \\
\text { ondary growth based on changes } \\
\text { in the stem structure. }\end{array}$ & $\begin{array}{l}\text { Concluding the occurrence of } \\
\text { secondary growth based on } \\
\text { changes in the root structure }\end{array}$ & $\begin{array}{l}\text { Distinguishing the structure of } \\
\text { trichome and papilla }\end{array}$ \\
\hline 11. & $\begin{array}{l}\text { Explaining the arguments on stem } \\
\text { secondary growth. }\end{array}$ & $\begin{array}{l}\text { Explaining the arguments on } \\
\text { stem secondary growth. }\end{array}$ & $\begin{array}{l}\text { Describing the abaxial leaf epi- } \\
\text { dermal structure }\end{array}$ \\
\hline 12. & & & $\begin{array}{l}\text { Describing the structure of the } \\
\text { leaf vessels }\end{array}$ \\
\hline 13. & & & $\begin{array}{l}\text { Concluding the leaf symme- } \\
\text { try based on the basic network } \\
\text { structure that compiling it }\end{array}$ \\
\hline
\end{tabular}

The data analysis was done both descriptively and quantitatively by calculating the proportion of learning indicator achievement. The mastery learning was the achievement of the minimal proportion of indicators at the minimum of 0.7 . Classical mastery was based on the percentage of learning achievement $\geq 70$ which was set at the $70 \%$ minimum for the students. The data analysis began with the differential test of ANOVA or Kruskal-Wallis (Trihendradi, 2012). The test was to see if there were significant differences in the outcomes among the three groups.

\section{RESULTS AND DISCUSSION}

Implementation of two problem-solving cycles was carried out for stem, root and leaf topic. The response variable was the achievement of problem-solving skill indicators and Plant Anatomy concept. The following will present the results for each of these variables.

\section{Problem-solving skills}

The learning outcomes of the problemsolving skills were measured through pre-test and post-test. The summaries of pre-test and post-test results obtained are presented in Table 2 .

Table 2. The Summary of the Problem-Solving Skill Learning Outcomes

\begin{tabular}{clcccc}
\hline Class & Topic & $\begin{array}{c}\text { Number of } \\
\text { Students }\end{array}$ & (Mean) & Std. Deviation & $\begin{array}{c}\text { N-gain } \\
\text { mean }\end{array}$ \\
\hline \multirow{2}{*}{ Biology Education A } & Pre-test & 36 & 49.08 & 11.78 & 0,303 \\
& Post-test & 36 & 65.61 & 08.09 & 0,364 \\
\multirow{2}{*}{ Biology Education B } & Pre-test & 41 & 43.58 & 10.59 & 10.71 \\
& Post-test & 41 & 64.41 & 09.76 & 0,335 \\
\multirow{2}{*}{ Biology Education U } & Pre-test & 17 & 48.23 & 10.80 & \\
\hline
\end{tabular}

Statistical analysis was performed on SPSS 16.0. The normality and homogeneity test results in derived from three class groups (A, B, and $\mathrm{U}$ ) showing normal and homogeneous data distribution. Different ANOVA test results on the Ngain pre-test and post-test of three classes showed that the three classes were not significantly different (significance value $0.32>0.05$, Ho accepted). Anova's different test results show that the three groups of classes were not significantly different. Therefore, it can be inferred that the learning management process conducted on the three groups 
were the same. The results of paired t-test between pre-test and post-test show that there were significant differences (the significance value of $0.000<0.05, \mathrm{H}_{0}$ rejected). The results of paired $\mathrm{t}$-test show that the learning management of the two problem-solving cycles gave an effect because the pre-test and post-test results were significantly different. The pre-test and post-test results were also analyzed to see the achieved mastery learning and the $\mathrm{N}$-gain obtained by each student categorized into low, medium and high. The data obtained are presented in Table 3.

Table 3. The Students Percentage of the N-Gain Predicate and Achieved Mastery Learning

\begin{tabular}{lllll}
\hline & $\begin{array}{l}\text { The Students } \\
\text { Percentage of } \\
\text { the N-Gain } \\
\text { Predicate }\end{array}$ & $\begin{array}{l}\text { Percentage of } \\
\text { the Students' } \\
\text { Completion }\end{array}$ \\
\cline { 2 - 5 } & Low & Medium & $\begin{array}{c}\text { Pre- } \\
\text { test }\end{array}$ & $\begin{array}{c}\text { Post- } \\
\text { test }\end{array}$ \\
\hline $\begin{array}{l}\text { Biology } \\
\begin{array}{l}\text { Education } \\
\text { A }\end{array}\end{array}$ & 50,00 & 50,00 & 22,22 & 80,60 \\
$\begin{array}{l}\text { Biology } \\
\text { Education } \\
\text { B }\end{array}$ & 31,70 & 68,29 & 7,75 & 65,90 \\
$\begin{array}{l}\text { Biology } \\
\text { Education }\end{array}$ & 41,10 & 58,80 & 17,64 & 82,35 \\
U & & & & \\
Mean & 40,93 & 59,03 & 15,87 & 76,28 \\
\hline
\end{tabular}

Table 3 tells the mean achievement of $\mathrm{N}$ gain was in the medium category, and the number of students who reach the average mastery learning was above the minimum $76.28 \%$. The accomplishment for each problem-solving skill indicator is presented in Figure 1.

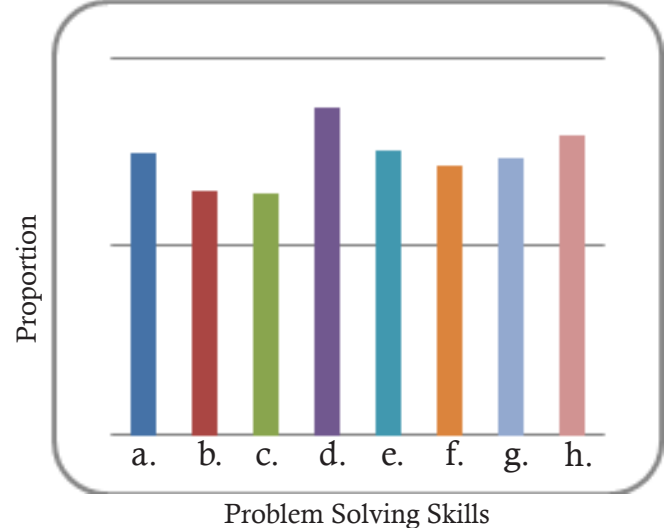

Information

a. Identifying facts;

b. Formulating questions;

c. Formulating temporary answers;

d. Identifying related factors;

e. Determining alternative problem solving;

f. Analysis of results;

g. Arranging work plan;

h. Arranging conclusions;

Figure 1. Learning Outcomes of Problem Solving Skills

Figure 1 describes the two unachieved indicators which were formulating questions and formulating a temporary answer. The indicatorswere achieved with the highest proportion on the identifying the related factors followed by the drawing a conclusion. Among the eight indicators, there were achieved six indicators, which means that the total number of the achieved indicators was $75 \%$.

\section{Plant Anatomy Concepts}

The learning results of plant anatomy concepts were obtained through the tests at the end of each course topic. The assessment instrument used has been validated by the experts. The statistical analysis results of the learning result score are presented in Table 4.

Table 4. The Learning Results of Plant Anatomy Concepts

\begin{tabular}{ccccc}
\hline Class & Topic & $\begin{array}{c}\text { Number of } \\
\text { Students }\end{array}$ & (Mean) & Std Deviation \\
\hline Biology Education A & Stem & 36 & 70.19 & 10.482 \\
& Root & 36 & 69.64 & 11.028 \\
& Leaf & 36 & 71.97 & 8.687 \\
Biology Education B & Stem & 41 & 71.56 & 11.726 \\
& Root & 41 & 68.44 & 10.252 \\
& Leaf & 41 & 71.12 & 7.349 \\
Biology Education U & Stem & 17 & 71.24 & 11.508 \\
& Root & 17 & 68.12 & 11.302 \\
& Leaf & 17 & 69.76 & 7.612 \\
\hline
\end{tabular}


The statistical analysis was performed on SPSS 16.0. Normality and homogeneity test results in data derived from the three class groups (A, B, and $\mathrm{U}$ ) show the normal and homogeneous distribution of the data. The results of Anova's difference test on the score of plant anatomy concept of the three classes showed that all classes were not significantly different (significance value $0.858>0.05$, Ho accepted). Anova's difference test results indicate that between the three groups of classes were not significantly different. Therefore, it can be interpreted that the learning management process conducted on the three groups were the same.

The learning results of plant anatomy concepts were also analyzed to see the achievement of mastery learning obtained by each student. The data were presented in Table 5 .

Table 5. The Percentage of the Students Achieving the Minimun Threshold of Mastery Learning on Plant Anatomy Concepts

\begin{tabular}{lcccc}
\hline \multirow{2}{*}{ Topic } & \multicolumn{4}{c}{ Percentage of achieved students } \\
\cline { 2 - 5 } & P.Biology A & P. Biology B & P. Biologi U & Mean \\
\hline Stem & 77,78 & 80,49 & 82,35 & 80,21 \\
Root & 77,78 & 73,17 & 64,71 & 71,88 \\
Leaf & 86,11 & 90,24 & 78,60 & 84,98 \\
\hline
\end{tabular}

Table 5 elucidates that the percentages of students who achieved the minimum threshold of mastery were $80.21 \%$ for stem topic, $71.88 \%$ for root topic and $84.98 \%$ for leaf topic. The indicator achievement was analyzed referring to the Plant Anatomy concepts for each topic, which can be seen in Table 5. The results of the indicator achievement analysis indicate that $80 \%$ of the indicators were accomplished, and the proportion of achievement was above 0.7. In addition, $20 \%$ of the unaccomplished indicator can be seen in Figure 2.

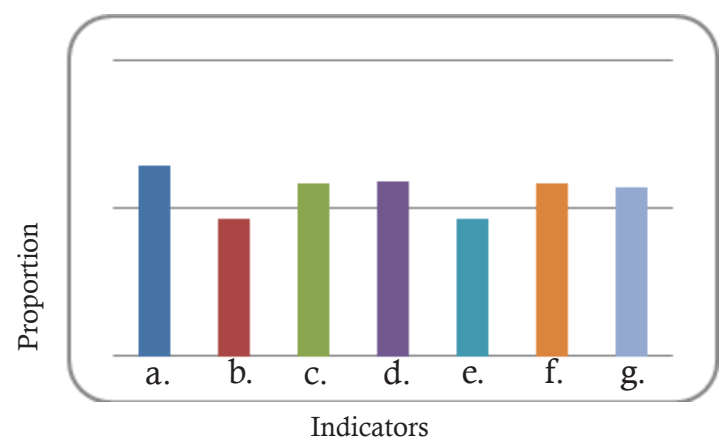

Information

a. Describing the stem endodermic structure;

b. Explaining the stem anomaly structure argument;

c. Describing the network structure of the root vessels composition;

d. Summing up the root anomaly structure;

e. Summing up the occurrence of secondary growth based on changes in root structure;

f. Describing systolic structure;

g. Describing the trichom structure based on its type.

Figure 2. Mastery Learning Accomplishment on the Unachieved Indicators
The implementation of two problem-solving cycles in the three class groups gave the same results in terms of Anova analysis, showing no other factors affecting the results obtained.

\section{Problem-solving Skills}

Previous research shows that problem solving skills can be mastered if presented in relation to material content (Racine, et al., 2011; Green, \& Ruggiero, 2017;). Problem solving learning is proven to help students develop the ability to discuss, ask, and think critically (Schmidt et al., 2011). Long research has shown that problem solving skills can be mastered by students through the management of learner-centered learning that is linked to daily life (Chang, et al., 2017). Other research shows that the results obtained are more likely to repeat concepts than the emergence of new concepts, and the imbalance between acquisition of concepts and problem solving skills (Yew, Chng, Schmidt, 2011; Prastiwi \& Indah, 2012).

Two effective problem-solving cycles have proven effective in achieving the learning outcomes of problem-solving skills. The implementation of two problem-solving cycles allowed repetition to practice problem-solving skills and examine concepts. It could increase memory through the activity of assessing knowledge to gain knowledge retention (Destalia, et al., 2014).

The problem-solving skill results between pre-test and post-test were significantly different, the completed indicator percentage was $75 \%$, having the mean of $\mathrm{N}$-gain in the medium category. The same N-gain category was also found in Wahyuni et.al., (2017). Other research studies have 
shown that problem-solving learnings have successfully fostered students' problem-solving and thinking skills in various academic fields (Eyler, 2009; Li et al., 2011, Hambach et al., 2016, Magdalena et al., 2014).

The overall results show that the two problem-solving cycles effectively achieved the goal of concept mastery and problem-solving skills (Lestari, 2016). Tackling the problem-solving skills is closely related to the material content. Instead, the material content will be mastered properly if the acquisition is through scientific ways of thinking in solving the problem. The learning process occurred in each problem-solving cycle always begin with presenting the problem of plant anatomy in the context of students (Riadi et al. 2017). Problems will enable preliminary knowledge that allows students to connect new information with the existing one (Sitti et al., 2013; Ristiasari et al., 2012).

The activity of formulating problems and planning the problem-solving steps allowed students to gain inquiry experience on complex tasks related to plant anatomical phenomena (Chang et al., 2017). The research results show the skills of formulating questions and answers were not achieved. In fact, these skills are highly dependent on critical thinking skills and breadth of material content. The skill of formulating tentative answers is something that requires a lot of skills prerequisites, such as Wahyuni's et al. (2017) research results, which also show the lowest score on it.

The skills of identifying related factors, determining alternative problem solving, formulating the work plan, analyzing the results, and drawing conclusions were achieved. This was closely related to the presentation of problems in the context of the students, and the first cycle learning process was also relevant to the concept of proximal development zone (Moreno, 2010). The process of exploring problem-solving was also relevant to the constructivist principle according to the BSCS, beginning with the Engaging phase (Invitation) (Carriger, 2015). In the problem-solving process, teachers do not provide knowledge, but students must seek and find it through the series of activities in which they act as a problem solver (Syofyan \& Halim, 2016). The approach differs from the approach which oriented to clarification, explanation, demonstration, and evaluation.

The average $\mathrm{N}$-gain on the problem-solving skills learning outcomes was in the medium category, showing an increase in the post-test compared to the pre-test. This increase was possible because there were repetitive learning processes, i.e. two cycles for each topic of study. The learning experiences in the first cycle can be a scaffolding for the second cycle (Amri, 2013; Slavin, 2011; Nurmaliah et al., 2013).

Two problem-solving cycles for each topic had the opportunity to develop critical thinking and problem-solving skills. The first cycle provided the experience to solve complex problems in the second cycle. For example, in the first cycle of stem topic, the students developed problemsolving steps to answer the question "what is the stem structure equation in related plants?". In the second cycle, the students solved the problem in a more complex context that was "how to structure the same plant type stems in the different environment?". The learnings let the students think critically and solve problems, as they dealt with specific conditions in the material content. It broke down the students' direct access to all information over the internet that might cause negative effects since they simply adopted information without analyzing, interpreting and critically thinking (Purcell et al., 2012).

\section{Plant Anatomy Concepts}

The learning outcomes of plant anatomy concept significantly show the achieved students percentage of $80,21 \%$ for stem topic, $71,88 \%$ for root topic, and $84,98 \%$ for leaf topic, the mastery learning completeness of the indicators scored $80 \%$.

Two concrete problem-solving cycles presented a number of plant anatomical phenomena as the learning materials. The students were trained to develop problems, gather information and design problem solving and provide explanations of the revealed phenomenon. This is in line with the opinion of Schmidt et al. (2011) and Destalia et al. (2014) who stated that problemsolving learning is characterized by presenting a carefully constructed set of problems and presenting it to groups of students.

The students were facilitated to discuss the problems and produce tentative explanations for the phenomena described in the problems. The set of problems presented could serve as modeling instruction, which had a positive impact on the research as what Sujarwanto et al. (2014) found in their research. The set of problems presented in this study were divided into two, namely the set of problems of cycle one and cycle two. The problems studied in the second cycle strongly supported the acquisition of metacognitive skills, as revealed by Herlanti et al., (2017) research that problem-solving strategies are the most effective strategies for increasing metacognitive knowled- 
ge. Another phenomenon arouse was the percentage of students who fully mastered the concept on the last topic (leaf) got the highest score. This might be due to the content materials on the leaf topic which repeated the main concepts that have been studied on the stem and root topic, e.g. the concept of xylem and phloem. Initial knowledge of the concepts studied on the leaf topics was sufficient, thus, the students could learn in their adequate zone of proximal development.

Other results indicate the unfinished Plant Anatomy concept indicators on stem and root topic related to the concept of secondary growth. The concepts were examined through the phenomena of stem and root anatomy. The acquisition of the basic concepts of the first cycle was not yet optimal, resulting in difficulties in dealing with other plant specimens from different classes in the second cycle. This reinforces the notion that learning to gain concepts must begin with the facts and definitions of concepts. Concept mastery passed through several levels, namely concrete level, identity, classification and formal (Ersoy, $\& \mathrm{Ba} \square$ er, 2014). The same things applied in the teaching of concepts whose stages begin with defining concept structures, defining concepts, constructing examples to ensure that examples possess multiple traits, and arranging and displaying sequences referring to the students' current knowledge (Promentilla et al., 2017). The learning processes about the development of secondary structures of stems and roots adopted the same steps. On the leaf topic, the low-achieved indicators were associated with identifying and describing the special epidermal derivatives found on the leaves. It is a relatively new concept on leaf topic.

The learning process built through two problem-solving cycles allowed the students to study anatomy through self-selected specimens. This led the intensity of the students to interact with a different anatomy fact proposed by other students. The intensity of interaction through the facts and concepts exploration of anatomy greatly affected the concept mastery as a result of learnings (Damopolii et al., 2015; Puspitawati, 2017). Facts and concepts exploration could be conducted because the presented examples of phenomena were related to plant anatomy, which triggered the students to think critically. It is relevant to the principle of the practical activity sheet development to support critical thinking on genetic topics (Susantini et.al., 2012). The results indicate that the context of learning could be a factor that contributes to the construction of problemsolving skills (Racine, et al., 2011; Green, \& Ruggiero, 2017)

\section{CONCLUSION}

The two problem-solving cycles in Plant Anatomy course were effective in achieving learning objectives of problem-solving skills and plant anatomy concepts. The data indicate a significant difference in students' problemsolving skills between pre-test and post-test with the $\mathrm{N}$-gain value is categorized as a medium level. Moreover, $75 \%$ of learning indicators have been completed by the students. Related to conceptual understanding, the results show that the percentages of students who could complete the topics of a stem, a root, and a leaf are 80,21\%, $71,88 \%$, and $84,98 \%$, respectively. Therefore, it is suggested that the two cycles of problem-solving cycles which were implemented in the current study were effective.

\section{REFERENCES}

Airey, J., \& Linder, C. (2009). A Disciplinary Discourse Perspective on University Science Learning: Achieving Fluency In a Critical Constellation of Modes. Journal of Research in Science Teaching, 46(1), 27-49.

Amisyah, S., \& Nurmaliah, C. (2015). Upaya Peningkatan Hasil Belajar Kognitif Melalui Model Problem Based Learning. BIOTIK: Jurnal Ilmiah Biologi Teknologi dan Kependidikan, 1(2), 87-92.

Amri, S. (2013). Pengembangan dan Model Pembelajaran dalam Kurikulum 2013. Jakarta: Prestasi Pustaka.

Carriger, S. (2015). Problem-Based Learning and Management Development-Empirical and Theoretical Considerations. The International Journal of Management Education, 13(3), 249-259.

Chang, C., Chang, Ming, Chiu, B., Liu, C., Chiang, S. Wen, C., Hwang, F., Wu, F., Chao, P., Lai, D., Wu, S., Chang, C., Chen, W. (2017). An Analysis of Student Collaborative Problem Solving Activities Mediated by Collaborative Simulations. Computers \& Education, 114, 222-235.

Chou, S.W., \& Chen, P,Y,. (2009). The Influence of Individual Differences on Continuance Intensions of Enterprise Resource Planning (ERP). International Journal of Human-Computer Studies, 67(6),345-355.

Cooperrider, D. L., \& Whitney, D. (2001). A Positive Revolution in Change: Appreciative Inquiry. Public administration and public policy, 87, 611-630. 
Creswell, W. J. (2014). Research Design: Qualitative, Quantitative, Mixed Method Approaches 4th Edition. USA: SAGE Publication.

Damopolii, I., Hasan, A., \& Kandowangko, N. (2015). Pengaruh Strategi Pembelajaran Inkuiri Bebas Dimodifikasi dan Kemampuan Memecahkan Masalah terhadap Keterampilan Proses Sains Mahasiswa Pada Praktikum Fisiologi Tumbuhan. Pancaran Pendidikan, 4(3), 191-200.

Demirel, M. (2015). A Study on the Relationship between Reflective Thinking Skills towards Problem Solving and Attitudes towards Mathematic. Procedia-Social and Behavioral Sciences, 197(2015), 2086-2096.

Destalia, L., Suratno., Apriliya S. (2014). Peningkatan Keterampilan Pemecahan Masalah Dan Hasil Belajar Melalui Penerapan Pembelajaran Berbasis Masalah (PBM) Dengan Metode Eksperimen Pada Materi Pencemaran Lingkungan. Jurnal Pancaran, 3(4), 213-224.

Dostal, J. (2015). Theory of Problem Solving. ProcediaSocial and Behavioral Sciences, 174(1), 2798-2805.

Effendi, D. (2016). Implementasi Model Creative Problem Solving untuk Meningkatkan Kemampuan Metakognitif Berdasarkan Kemampuan Awal Matematis. JPPM, 9(2), 164-176.

Ersoy, E., \& Baser, Nes'e. (2014). The Effects of Problem-Based Learning Method in Higher Education on Creative Thinking. Procedia - Social and Behavioral Sciences, 116(2014), 3494 - 3498.

Eyler, J. (2009). The Power of Experiential Education. Liberal Education, 95 (4), 24-31.

Finch, L.,Crunkilton, A. (1999). Curiculum Development in Vocational Technical Education. Boston: Allyn and Bacon.

Fischer, A., Greiff, S., Wüstenberg, S., Fleischer, J., Buchwald, F., \& Funke, J. (2015). Assessing Analytic and Interactive Aspects of Problem Solving Competency. Learning and Individual Differences, 39, 172-179.

Fraenkel, J. R., Wallen, N. E., \& Hyun, H. H. (2012). How to Design and Evaluate Research in Education (8th ed.). New York: McGraw-Hill.

Gilles, C. N. R., Kratochwill, T. R., Felt, J. N., Schienebeck, C. J., \& Vaccarello, C. A. (2011). Problem Solving Consultation: Applications in Evidence-Based Prevention and Intervention. In The Oxford Handbook of School Psychology.

Gormally, C., Brickman, P., Hallar, B., \& Armstrong, N. (2009). Effects of Inquiry-Based Learning on Students' Science Literacy Skills and Confidence. International journal for the scholarship of teaching and learning, 3(2), 16-22.

Green, L., \& Ruggiero, D. (2017). Problem Solving through Digital Game Design: A Quantitative Content Analysis. Computers in Human Behavior, 73, 28-37.

Hambach, J., Diezemann, C., Tisch, M. (2016). Assessment of Students' Learn Competencies with the Help of Behavior Video Analysis-Are Good Students Better Problem Solver?.Procedia CIRP, 55(2016), 230 - 235.
Henderson, M., Lee,S., Whitaker, G., Altman, L. (2011). Positive Problem-Solving: How Appreciative Inquiry Works. Strategies and Solutions for Local Government Managers, 43(3), 247-258.

Herlanti, Y., Mardiati, Y., Wahyuningtyas, R., Mahardini, E., Iqbal, M., Sofyan, A. (2017). Discovering Learning Strategy to Increase Metacognitive Knowledge on Biologu Learning in Secondary School. Jurnal Pendidikan IPA Indonesia, 6(1), 179-186.

Hoskinson, A.M., Caballero, M.D., Knight, J.K. (2013). How Can We Improve Problem Solving in Undergraduate Biology? Applying Lessons from 30 Years of Physics Education Research. CBE-Life Sciences Education, 12(2), 153-161.

Isari, D., Pontiggia, A., \& Virili, F. (2016). Working with Tweets vs. Working With Chats: An Experiment on Collaborative Problem Solving. Computers in Human Behavior, 58, 130-140.

Jayaram, J., Das, A., \& Nicolae, M. (2010). Looking beyond the Obvious: Unraveling the Toyota Production System. International Journal of Production Economics, 128(1), 280-291

Kirmizi, O. (2015). The Interplay among Academic Self-Concept, Self-Efficacy, Self-Regulation and Academic Achievement of Higher Education L2 Learners. Journal of Higher Education \& Science/Yuksekogretin ve Bilim Dergisi, 5(1), 3240

Lesh, R. \& Zawojewski, J. S. (2007). Problem Solving and Modeling. In F. Lester (Ed.).The Second Handbook of Research on Mathematics Teaching and Learning. Charlotte, NC: Information Age Publishing.

Lestari, S. (2016, January). Analisis Kemampuan Technological Pedagogical Content Knowledge (TPACK) pada Guru Biologi SMA dalam Materi Sistem Saraf. In Prosiding Seminar Biologi (Vol. 12, No. 1, pp. 557-564).

Li, Yuzhu., Yang, M., Klein, G., \& Chen, H. (2011). The Role of Team Problem Solving Competency in Information System Development Projects. International Journal of Project Management, 29(7), 911-922.

Magdalena, O., Mulyani, S., Susanty, E. (2014). Pengaruh Pembelajaran Model Problem Based Learning Dan Inquiry Terhadap Prestasi Belajar Siswa Ditinjau Dari Kreativitas Verbal Pada Materi Hukum Dar Kimia Kelas X Sman 1 Boyolali Tahun Pelajaran 2013/2014. Jurnal Pendidikan Kimia (JPK), 3(4), 162-169.

Mavinkurve, M., \& Patil, M. (2016). Impact of Simulator as a Technology Tool on Problem Solving Skills of Engineering Students-A Study Report. Journal of Engineering Education Transformations, 29(3), 124-131.

Moreno, R. (2010). Educational Psychology. New York: John Wiley \& Sons, Inc.

OECD. (2013). PISA Result (Volume V): Creative Problem Solving: Students' Skills in Tackling Real-Life Problems. Paris : OECD Publishing. 
OECD. (2014). PISA Results (Volume IV): What Students Know and Can Do - Student Performance in Mathematics, Reading and Science. Paris : PISA OECD Publishing.

OECD. (2016). PISA Results (Volume I): Excellence and Equity in Education, Paris : OECD Publishing. Retrieved From http://dx.doi.org/10.1787.

Phungsuk, R., Viriyavejakul, C., \& Ratanaolarn, T. (2017). Development of a Problem-Based Learning Model Via a Virtual Learning Environment. Kasetsart Journal of Social Sciences, 38(3), 297-306.

Prastiwi, M. S., \& Indah, N. K. (2012). Profil Perangkat Pembelajaran Taksonomi Tumbuhan Tinggi Berbasis Proyek Untuk Melatih Mahasiswa Berpikir Kreatif. In Seminar Nasional VII Pendidikan Biologi (Vol. 9, No. 1, pp. 241-249).

Promentilla M.A.B., Lucas, R.I.G., Aviso, K.B., Tan, R.R. (2017). Problem-Based Learning of Process Systems Engineering and Process Integration Concepts with Metacognitive Strategies: The Case of PGraphs for Polygeneration Systems, Applied Thermal Engineering, 127, 1317-1325.

Purcell, K., Rainie, L., Heaps, A., Buchanan, J., Friedrich, L., Jacklin, A., ... \& Zickuhr, K. (2012). How Teens Do Research in the Digital World. Pew Internet \& American Life Project.

Puspitawati, R. P. (2017). Strategi Penyelesaian Masalah Pada Perkuliahan Anatomi Tumbuhan Untuk Menumbuhkan Keterampilan Berfikir Melalui Ide Inovatif. Jurnal Pendidikan Biologi, 6(2), 108-116.

Riadi, M., Armi, A., \& Surya, E. (2017). Keterampilan Proses Sains Berbasis Inquiry Pada Praktikum Botani Tumbuhan Rendah Pada Calon Guru Pendidikan Biologi FKIP Pendidikan Biologi Universitas Serambi Mekkah. Jurnal Biology Education, 6(2).

Riantoni, C., Yuliati, L., Mufti, N., Nehru. (2017). Problem Solving Approach in Electrical Eneergy and Power on Students as Physics Teacher Candidates. Jurnal Pendidikan IPA Indonesia, 6(1), 55-62.

Ristiasari, T., Priyono, B., Sukaesih, S. (2012). Model Pembelajaran Problem Solving Dengan Mind Mapping Terhadap Kemampuan Berpikir Kritis Siswa. Journal Biology Education, 1(3), 34-41.
Rotherham, A. J., \& Willingham, D. T. (2010). "21stCentury" skills. American Educator, 17, 17-20.

Schmidt, H.G., Rotgans, J.I \&, Elaine H.J., Yew, E.H. (2011). The Process of Problem-Based Learning: What Works And Why. Medical Education, 45(8), 792-806.

Sitti, S., Sopeerak, S., \& Sompong, N. (2013). Development of Instructional Model Based on Connectivism Learning Theory to Enhance ProblemSolving Skill in ICT for Daily Life of Higher Education Students. Procedia - Social and Behavioral Sciences, 103, 315 - 322.

Slavin, Robert. E. (2011). Educatinal Psycologies, Theories and Practice. Pearson Education, Inc. New York.

Sujarwanto, E., Hidayat, A., \& Wartono, W. (2014). Kemampuan Pemecahan Masalah Fisika Pada Modeling Instruction Pada Siswa SMA Kelas XI. Jurnal Pendidikan IPA Indonesia, 3(1), 65-78.

Susantini, E., Thamrin, M., Isnawati, Lisdiana, L. (2012). Pengembangan Petunjuk Praktikum Genetika Untuk Melatih Keterampilan Berpikir Kritis. Jurnal Pendidikan IPA Indonesia, 1(2), 102-108.

Syofyan, H., \& Halim, A. (2016). Penerapan Metode Problem Solving Pada Pembelajaran IPA Untuk Peningkatan Kemampuan Berpikir Kritis Siswa. In Prosiding Seminar Nasional Multi Disiplin Ilmu \& Call For Papers UNISBANK (SENDI_U) KE-2 Tahun.

Trihendradi, C. (2012). SPSS 20 Analisis Data Statistik. Yogyakarta: Andi.

Tuckman, W. B. \& Harper, E. B. (2012). Conducting Educational Research. USA: Rowman \& Littlefield Publishers.

Wahyuni, S., Indrawati, Sudartin, Suana, W. (2017). Developing Science Process Skills and Problem-Solving Abilities Based on Outdoor Learning in Junior High School, Jurnal Pendidikan IPA Indonesia, 6(1), 165-169.

Wang, Y., \& Chiew, V. (2010). On the Cognitive Process of Human Problem Solving. Cognitive Systems Research, 11(1), 81-92.

Yew, E.H.J., Chng, E., Schmidt, H.G., (2011). Is Learning in Problem-Based Learning $\mathrm{Cu}-$ mulative?. Advances in Health Sciences Education, 16(4), 449-464. 